Kevin L. Kliesen and John A. Tatom

Kevin L. Kliesen is an economist and John A. Tatom is an assistant vice president at the Federal Reserve Bank of St. Lovis. James P. Kelley provided research assistance. This article was written while Tatom was a visiting economist at the Austrian National Bank. Tatom received useful comments in seminars on this paper at the Bank of the Netherlands, the Swiss National Bank and the institute of Advanced Studies in Vienna.

\title{
The Recent Credit Crunch: The Neglected Dimensions
}

HONVENTIONAL WISDOM HAS IT THAT a credit crunch occurred in the U.S. economy in 1990-92, causing, or at least contributing to, the latest recession and jeopardizing the strength of the recovery. Much has been written about the causes and consequences of the credit crunch and about remedies for it.

While the term is widely used, the precise definition of a credit crunch is not widely agreed upon. Credit crunches have in common, however, a slowing in the growth of -or an outright decline in-the quantity of credit outstanding, especially business loans at commercial banks. Analysts who espouse the credit crunch theory typically have a more specific definition in mind. In their view, a credit crunch arises from a reduction in the supply of credit. Accordingly, this article uses the term "credit crunch" to refer only to a reduction in the supply of credit. It addresses the credit crunch hypothesis by examining the existence and implications of competing potential sources of a decline in credit, including the recent

The Chairman of the Federal Reserve System, Alan Greenspan, has expressed concern over the slowing in credit growth and the extent to which it was induced by bank regulators' attempts to raise bank capital. See Greenspan (1991). Other Federal Reserve officials who have expressed concern over the credit crunch during this period include LaWare (1991), Forrestal (1991) and Syron (1991). Concern over a potential global credit crunch has been raised by the Bank for International Settlements (1991) and Japan's Economic Planning Agency [see Reuters (1991a)]. Concern for a national crunch has also surfaced in France [see Reuters (1991b)]. Also see O'Brien and Browne (1992). behavior of interest rates, interest rate spreads and commercial bank business loans. This paper suggests that recent movements in short-term interest rates and changes in relevant interest rate spreads cast doubt upon the conventional credit crunch view.

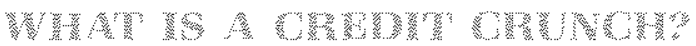

The traditional notion of a credit crunch originally involved the process known as disintermediationa decline in savings-type deposits at banks and savings and loans that result in a decline in bank lending." Episodes of disintermediation occurred when market interest rates, especially rates on Treasury bills and commercial paper, rose above Regulation $\mathrm{Q}$ interest rate ceilings at these financial institutions. As this occurred, depositors withdrew their funds from banks and savings and loans to invest at higher open market rates, and bank credit, especially for business loans, fell.

2See Kaufman (1991) for a discussion of the origin of this term in his work with Sidney Homer and for a brief sketch of the history of credit crunches. For detailed analysis of previous credit crunches, see Wojnilower (1980). 
The phrase "credit crunch" was coined in mid-1966 when the Federal Reserve's monetary policy became more restrictive; the Fed wanted to slow the growth of demand for goods and services in order to fight inflation. ${ }^{3}$ In 1966, the Fed's actions to slow the growth of money and credit were reinforced by allowing short-term interest rates to rise above the Regulation $\mathrm{Q}$ ceiling rate on bank deposits. As a result, depositors withdrew their funds from regulated deposits to seek higher market rates. The reduction in bark deposits, in turn, limited banks' ability to lend and their supply of credit. What made this event significant was the Fed's refusal to accommodate the rise in short-term market interest rates by raising the Regulation $\mathrm{Q}$ ceiling rates at banks and savings and loans, as it had done in the past. ${ }^{4}$ Since financial deregulation in the early 1980s ended interest rate ceilings, such regulatory-induced disintermediation can no longer occur.

A more encompassing view of a credit crunch is based on any non-price constraint on bank lending, not simply on disintermediation. In its recent application, the source of this constraint has presumably been the response by bankers to increased regulatory oversight and their own reaction to recent deterioration of bank asset values and profitability. Increased savings and loan failures, as well as increased capital requirements, may also have played a part. ${ }^{5}$

This broader definition of a credit crunch has been summarized by the Council of Economic Advisers (1992):

A credit crunch occurs when the supply of credit is restricted below the range usually identified with prevailing market interest rates and the profitability of investment projects. (p. 46)

${ }^{3}$ As a result of this policy action, interest rates rose and credit became more scarce. For example, in the third quarter of 1966, the interest rate on three-month Jreasury bills rose above 5 percent for the first time in more than 30 years; the 5.04 percent average rate during the quarter was up sharply from the 4.59 percent rate in the previous quarter. The growth of the money stock (M1) had already slowed from a 7.3 percent annual rate in the two quarters ending in the first quarter of 1966 to a 4.3 percent rate in the second quarter of 1966. This was followed by a decline at a 1.2 percent rate in the third quarter and a 1.2 percent rate of increase in the last quarter of 1966. See Burger (1969) and Gitbert (1986) for discussions of this episode.

4 According to Burger (1969), p. 24, the Fed previously accommodated the rise in rates in July 1963, November 1964 and December 1965 by raising the Regulation $Q$ ceiling. This behavior is also discussed by Woinilower (1980). One flaw with the disintermediation view is that a decline in intermediation through banks does not reduce the total supply of
A credit crunch, either through disintermediation, overzealous regulators or banks' unwillingness to lend for some other reason, is therefore usually thought of as a supply phenomenon. The flow of eredit, however, results from the interaction of both credit supply and credit demand. In other words, while supply considerations could certainly result in a decline in credit flows, a reduction in the demand for credit could produce the same result. Fortunately, economic theory indicates a criterion for assessing which of these is the dominant source of a change in the quantity of credit.

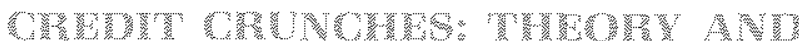 B.}

Figures $1 \mathrm{a}$ and $1 \mathrm{~b}$ illustrate the typical analysis of the credit market aspects of a credit crunch using the supply and demand framework for credit flows. In this framework, the quantity of credit demanded varies inversely with the cost of creditthat is, the interest rate-given other factors that influence overall demand for credit. Conversely, the quantity supplied of credit increases with the interest rate, given the other factors that influence credit supply decisions. ${ }^{6}$ We will examine two scenarios. The first illustrates the credit crunch hypothesis, namely, a reduction in the quantity of credit supplied resulting from reduced bank willingness to lend. The second scenario offers an alternative. In this case, a reduction in the demand for bank credit occurs. As will be explained below, this could be the result of a decline in business demand for credit associated with a reduction in inventory investment. ${ }^{7}$

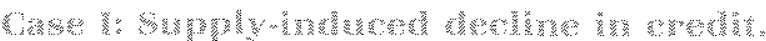
In figure 1a, an equilibrium in the credit market

credit unless some of the funds removed from banks are not funneled into other credit instruments like Treasury bills or commercial paper.

${ }^{5}$ The latter idea is closely associated with Syron (1991), who has termed the reduction in lending as a "capital crunch." Greenspan (1991) has also supported efements of this argument, as has the Council of Economic Advisers (1992). Also see Bemanke and Lown (1991) for a different perspective on this hypothesis.

6Figures ta and $1 \mathrm{~b}$ are drawn conditionally on an expected rate of inflation. That is, the standard assumption that expected inflation is not a cyclical phenomenon during business recessions is employed. Therefore, in this framework, a change in a nominal variable is also a change in a real variable.

7Figures $1 \mathrm{a}$ and 10 are not meant to imply that bank credit determines the level of economic activity. For alternative explanations about the linkage between bank credit and economic activity, see the shaded insert on p. 24. 
Figure 1a

\section{Decline in the Supply of Credit}

\section{Case I: Reduced willingness to lend}

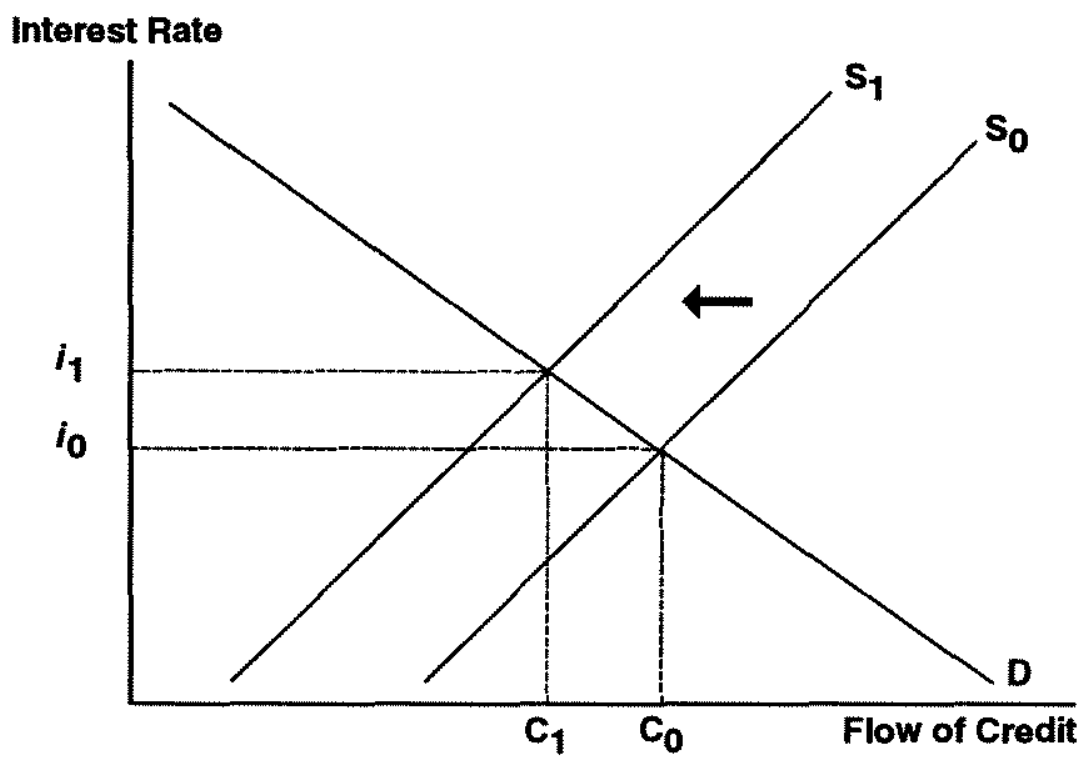

Figure 1b

Decline in the Demand for Credit

Case II: Reduced loan demand by businesses

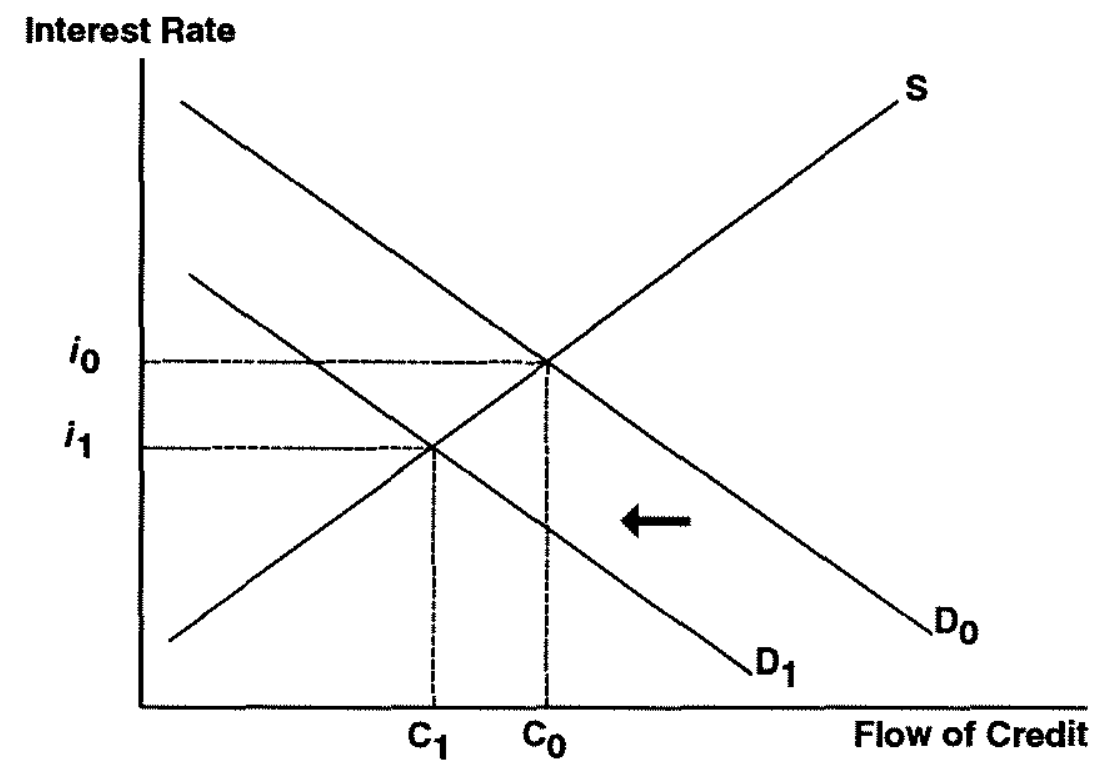


Figure 2

\section{Quarterly Change in Domestic Nonfinancial Debt as a Percent of GDP}

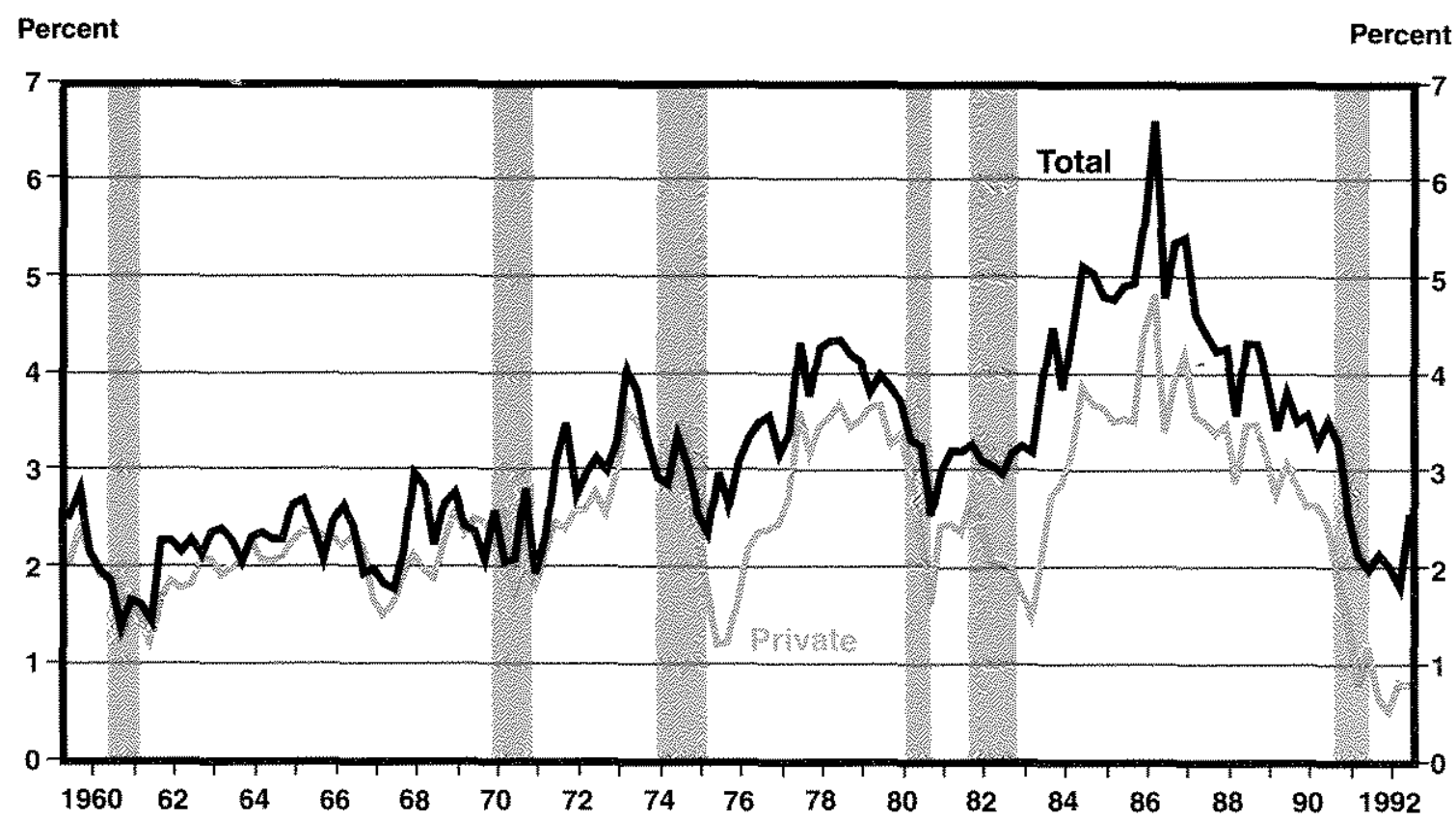

Periods of business recession are indicated by the shaded areas.

exists at interest rate $i_{i 0}$ with a flow of credit equal to $C_{0}$. If one of the other factors influencing the supply of credit shifts-for example, if there is a reduced willingness on the part of banks to supply credit at a given interest rate-then the initial supply schedule $\left(S_{0}\right)$ will shift leftward to $\mathrm{S}_{1}$. As a result, the market interest rate will rise to $i_{1}$ to eliminate the shortage of credit and thus the quantity of credit will fall to $\mathrm{C}_{1}$.

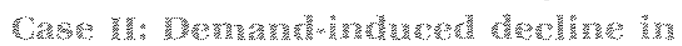
cosecents The quantity of credit can also fall because the demand for bank credit declines. This is shown in figure $1 \mathrm{~b}$. As before, the quantity supplied and quantity demanded for credit are initially in equilibrium at $\mathrm{C}_{0}$ and $\mathrm{i}_{0}$. As the demand for credit falls, an excess supply of credit develops. Accordingly, the interest rate will decline to a new equilibrium level $\left(i_{1}\right)$-the

sit is possible for a reduction in the supply of credit to occur in conjunction with a decline in the interest rate, but this still requires that the demand for credit declines (shifts to the left) by more than the supply of credit. Thus, the dominant point where quantity demanded and quantity supplied are once again equated.:

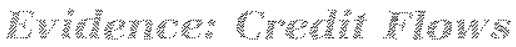

The central feature of a credit crunch-a decline in the growth of credit-has occurred in every period that has been identified as a credit crunch. Such periods also tend to be recessions. For example, Kaufman (1991) cites credit crunches that occurred in 1959, 1969-70, the mid-1970s, 1981-82 and 1990-91. Except for the first, these periods correspond to each of the recessions that have occurred since the late 1950s. The first instance, in 1959 , preceded the ony other recession since then, the recession from II/1960 to $\mathrm{I} / 1961$.

Figure 2 shows two measures of the flow of credit, namely the quarter-to-quarter change in

impulse accounting for the decline in the quantity of credit would remain the shift in demand. Proponents of the credit crunch view, however, emphasize the supply channel as the principle source of the reduction in credit. 
Figure 3

\section{Short- and Long-Term Interest Rates}

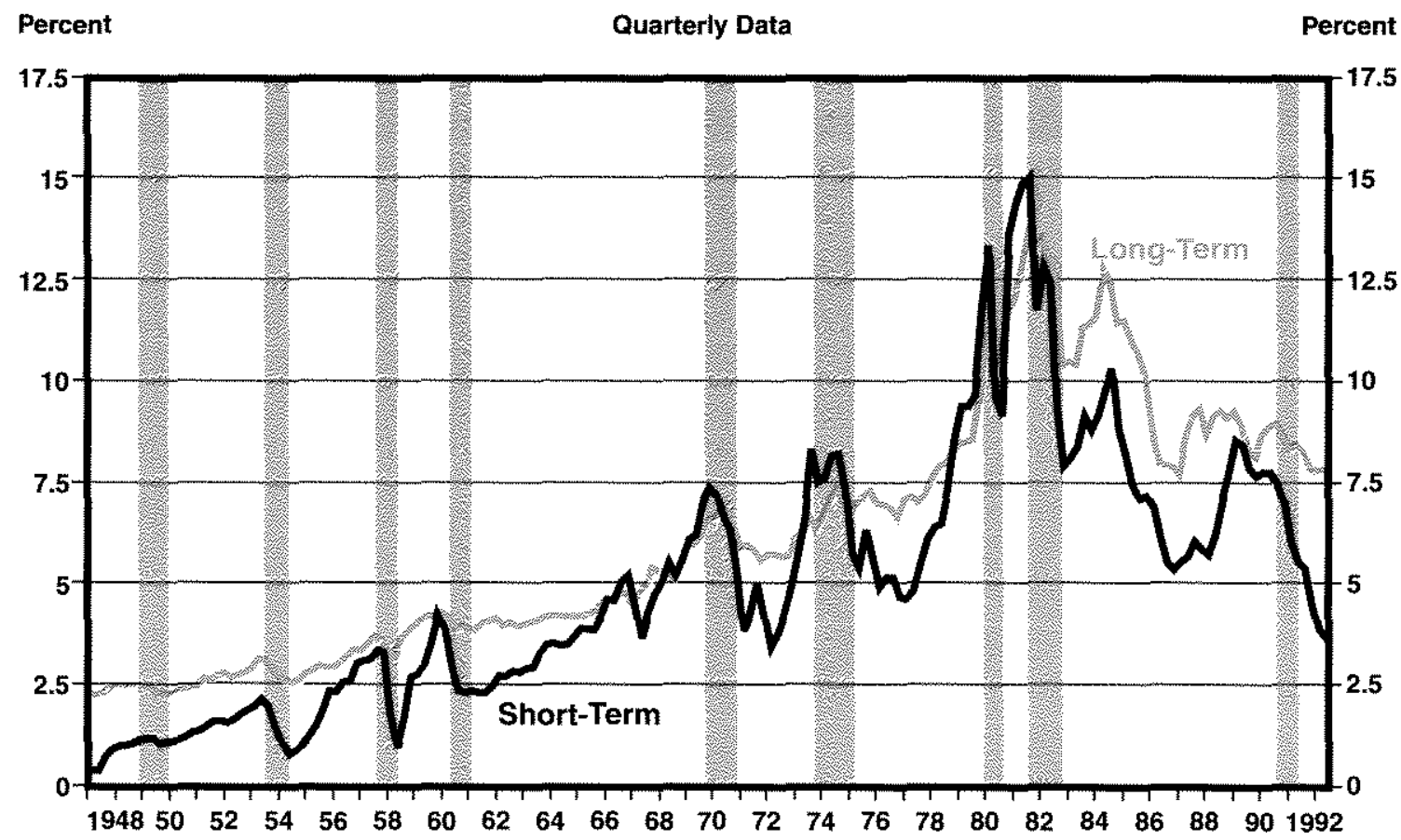

Periods of business recession are indicated by the shaded areas.

private domestic nonfinancial debt (excluding federal debt) and the change in total domestic nonfinancial debt-both expressed as a percent of gross domestic product (GDP). Typically, in recessions, the rate of debt accumulation declines relative to GDP. ${ }^{9}$ This reflects the fact that credit growth tends to be cyclical, especially the growth of private credit; typically, credit growth slows relative to GDP during recessions and rises during expansions ${ }^{10}$ Thus, it is not possible to ascertain from figure 2 whether the decline in credit in each instance caused the recession or was merely a reflection of the recession. To determine that, one must look at interest rate movements over the business cycle.

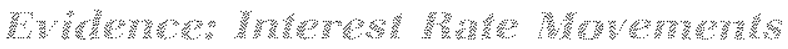

The two scenarios shown in figure 1 provide us with a stark contrast: In figure 1a, the decline in credit results in a rise in the interest rate, while in figure $1 \mathrm{~b}$, the decline in credit is associated with a decline in the interest rate. A rise in interest rates, however, is not typical in recessions. Figure 3 shows a long-term interest rate
9 The cyclical behavior of public sector deficits and overall credit demand and its implication for interest rates is discussed in more detal in Tatom (1984 and 1985).

${ }^{10}$ Another factor influencing the private demand for credit, particularly business credit, is business' use of internally generated funds to finance investment. The significance of the cyclical behavior of these funcs is developed by Gilbert and Ott (1985). Internal funds include retained eamings and depreciation allowances. When a firm's investment exceeds its internally supplied funds, it must turn to external financing to bridge this gap. Conversely, when internal funds exceed investment flows, a firm does not necessarily require external financing. For nonfinancial corporations, the ratio of fixed investment (plant and equipment) and inventory investment to internal funds is greater than one during cyclical expansions, but usually falls below one during recessions, exhibiting the same cyclical nature of credit demand. During the seven recessionary periods from 1953 to 1982 , the average ratio fell from 1.24 at the business cycle peak to 1.01 at its trough. A similar pattern developed in the most recent recession. In the inird quarter of 1990 , this ratio stood at 1.15 ; by the second quarter of 1991, it had fallen to 0.89 . Thus, internal funds were relaively more abundant for financing investment, so less external financing, including bank credit, was demanded. 
Table 1

The Federal Funds Rate and the Business Cycle

Federal Funds Rates (percent)

\begin{tabular}{lccc}
$\begin{array}{l}\text { Business cycle } \\
\text { peak/trough }\end{array}$ & $\begin{array}{c}\text { At business } \\
\text { cycle peak/ } \\
\text { trough }\end{array}$ & At closest peak & At closest trough \\
\hline III/1957-II/1958 & $3.24 / 0.94$ & SAME & SAME \\
II/1960-I/1961 & $3.70 / 2.00$ & $3.99(-2)$ & $1.68(+2)$ \\
IV/1969-IV/1970 & $8.94 / 5.57$ & $8.98(-1)$ & $3.86(+1)$ \\
IV/1973-I/1975 & $10.00 / 6.30$ & $10.57(-1)$ & $5.41(+1)$ \\
I/1980-III/1980 & $15.07 / 9.83$ & SAME & SAME \\
III/1981-IV/1982 & $17.59 / 9.28$ & $17.79(-1)$ & $8.66(+1)$ \\
III/1990-II/1991 & $8.16 / 5.86$ & $9.73(-5)$ & $3.77(+4)^{2}$ \\
\hline
\end{tabular}

The number of quarters easler $(-)$ or later $(+)$ in which the closest federal funds rate peak or trough occurs is indicated in parentheses.

Latest data available.

(the yield on long-term government bonds) and a short-term interest rate three-month Treasury bills) since 1947. Typically, both long- and shortterm interest rates decline during recessions, although the long-term rate is much less cyclical than the short-term rate. Indeed, short-term interest rates sometimes reach a peak before the business cycle peak. In the latest instance, in particular, the three-month Treasury bill rate peaked at 8.54 percent in the first quarter of 1989 , six quarters before the business cycle peak.

An alternative measure of short-term interest rate movements is the interest rate in the federal funds market. Briefly, the fed funds market is the market in which banks compete daily for excess reserves to meet their level of required reserves. Since the fed funds market is heavily influenced by Federal Reserve policy actions (through open market operations), some analysts believe that the behavion of this key short-term rate can provide direction about the relative tightness of bank credit.11 Accordingly,

\footnotetext{
"Since the Fed and banks create money largely by acquiring debt instruments (loans and investments in debt issued by governments, firms and individuals), analysts typically use the terms money and credit interchangeably. Some analysts, like Kaufman, regard the principal channel of influence of monetary policy to be its effect on credit, not on the money stock or other measures of monetary assets. Kahn (1991) suggests that the linkage between bank loans and monetary aggregates is weak, so that a slowing in monetary growth could not have caused bank loan growih
}

since credit crunches are allegedly the result of Federal Reserve policy actions to reduce credit availability, the interest rate in the federal funds market may be a more useful indicator.

Table 1 shows the average federal funds rate at the business cycle peak and trough and the nearest peak and trough of the rate itself. The fed funds rate typically peaks before or at the business cycle peak, suggesting that the type of supply shift shown in figure la does not occur during recessions. Like the three-month Treasury bill rate, the fed funds rate typically falls before and during recessions.

There are periods, of course, when short-term interest rates rise and the flow of credit declines. Figures 2 and 3 support the earlier discussion which indicated that such developments occurred in 1966 and, to a certain extent, over stretches during the period 1986-88. Interest rates and the demand for credit, however, tend to be procyclical, both when the economy is in recession

to fall in 1990 nor could an increase in money growth have raised bank lending. Walsh (1991) argues that the recent credit crunch reffects a decline in the demand for credit, not in its supply, and that traditionat monetary policy actions can change the supply of credit independently of bankers' wilingness to make loans. Some analysts look at the excess reserve holdings of commercial banks as an indicator of a credit crunch, but Hatbrich (1991) finds this measure an unreliable indicator of credit conditions. 


\section{Bank Credit and Economic Activity}

Many analysts attribute a central, causal role in business cycle developments to bank credit movements, regardless of the reasons for such movements. For example, some researchers suggest that it is the interplay of credit and real economic activity that provides banks and monetary institutions with a potentially direct role in business cycle developments. In particular, they view the growth of the money stock as purely passive, responding to the general movements of the economy, while disruptions to credit markets have real consequences for output and employment decisions. Thus, in this view, a decline in credit supply is critically important in causing and maintaining recessionary conditions. ${ }^{2}$

A related view assigns a special role to banks in extending credit and promoting economic activity. This view emphasizes that many firms are relatively small and have limited access to organized financial markets (for example, the commercial paper market). Accordingly, these firms' ability to expand is constrained by their access to bank credit. ${ }^{3}$ The special role of banks, then, is to provide objective evaluations and monitoring services for the continuing viability and credit-worthiness of this relatively large sector of the economy. Thus, one dollar of bank credit is not a perfect substitute for one dollar of other credit, like a direct personal loan or the proceeds from selling commercial paper.
Bank credit carries with it the banker's certification of credit-worthiness and the banker's implicit contract for future monitoring services, the provision of financial advising and other financial services. Furthermore, extensions of bank credit to firms provide information to potential customers, financiers and other suppliers about the firm's economic prospects. In this view, not only does the supply of credit play a unique role, independent of monetary policy developments, but bank credit is also the principal linchpin for the influence of financial market developments on real economic activity.

Whether a slowing in the growth of business loans is considered a source of recessionary pressures on economic activity or simply a reflection of the recession is important to both business cycle analysts and policymakers. If the supply of credit plays a central role and is not simply a reflection of monetary aggregate movements, then policymakers may need tools to operate specifically on the credit supply. If credit movements do not change independently or exert an independent influence, however, traditional monetary policies-namely, open market operationscan reliably address cyclical problems; credit market conditions will provide no more than useful supporting information.
1This is known as the "credit view" of the transmission mechanism. Gertter (1988) reviews the literature on the effects of credit market shocks. See also Gertler and Hubbard (1988) and Bernanke (1986). Bernanke (1983) and Hamiton (1987) argue for an independent role of credit in explaining the Great Depression. The credit view is an extension of the approach taken by real business cycle (RBC) researchers. See, for example, Plosser (1991).

${ }^{2}$ Analyses of the unique role of bank credit sometimes focus on changes arising from changes in reserve requirements. Since reserve requirement changes affect bank credit, given deposits, it is easy to infer that bank credit can change independently of movements in money. Such analyses ignore the role of the Federal Reserve. A change in bank credit because of a change in reserve requirements, however, results in an equal and offsetting change in credit supplied by Federal Reserve Banks, as the Fed accommodates the change in demand for requited reserves available by buying or selling securities or other assets. Accordingly, there is no change in the net total of credit associated with a given money stock and adjusted monetary base. Thus, movements in credit or money during such episodes are not especially unique compared with those in periods when reserve requirements do not change.

${ }^{3} \mathrm{~A}$ related argument stresses segmented markets, so that relatively small firms have no access to organized capital markets. Blinder and Stiglitz (1983) discuss the independent function of bank loans. James (1987) provides evidence supporting the view that bank loan extensions raise the value of firms. Judd and Scadding (1981) were the first analysts to model an independent role for bank toans to cause changes in the money stock. See Anderson and Rasche (1982), however ${ }_{f}$ for a critical discussion of their model. More recently, analysts have focused on the structure of loan contracts and on loan commitments as a mechanism for avoiding credit rationing. See Duca and VanHoose (1990) for a model of the effects of loan commitments on optimal monetary policy. 
and when it is not ${ }^{12}$ In the latest instance, in fact, interest rates and credit flows were declining well before the economy entered the recession. Thus, the evidence presented in this section is consistent with the hypothesis that, during episodes that have been characterized as credit crunches, the factors that affect the demand for credit tend to outweigh any possible effects from factors influencing the supply of credit ${ }^{13}$ The appropriate interpretation of credit market developments during the latest "credit crunch" is that illustrated in figure $1 \mathrm{~b}$.

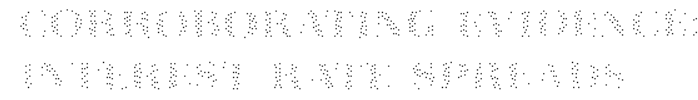

Economists have long pointed to the informational content of interest rate spreads for economic activity ${ }^{14}$ This observation stems from the fact that certain credit market instruments have similar characteristics and are more or less substitutable. Thus, if the interest rate on one instrument changes relative to its substitute, this may provide information about the behavior of credit market participants. For example, evidence of unusual bank lending behavior might be obtained by looking at the difference between bank lending rates and the rates banks pay for deposits or between rates available at banks and those available elsewhere.

This "pricing" behavior of banks has a direct application in examining credit market conditions. If banks become more reluctant to lend, then the interest rate at which they lend (bank loans) should rise relative to the interest rate at which they borrow (deposits). This is a poor test, how. ever, because periods when credit crunches are believed to occur also tend to be periods of recessions, when the bankruptcy rate and default rates on business loans rise. Thus, the spread between a bank's lending and borrowing rates should rise to compensate for these risks. Therefore, while interest rate spreads cannot provide definitive support for the existence of a credit crunch, they can provide some evidence about the comparability of the most recent episode by comparing the recent spreads with earlier ones.

Figure 4 shows the quarterly interest rate spreads for some relatively risky short- and long-term securities from 1947 to the present. The shortterm spread measures the prime rate relative to the interest rate on three-month Treasury bills, while the long-term spread is the excess of riskier BAA bond yields over AAA bond yields ${ }^{15}$ Thus, a rise in the spread indicates an increase in risk.

During recession periods, the spread on risky assets rises, especially the short-term spread, because-as figure 4 shows-that is where most of the risk is. The rise in rates banks charge on loans that are inherently more risky in recessionsrelative to their costs on insured deposits-need not reflect a new reluctance to lend beyond that arising from recession risk. Compared with the rise in spreads (on risky assets) in previous recessions, however, the recent spreads did not rise unusually. In fact, the long-term spread actually fell in 1991 before the recession ended.

a credit crunch and they emphasize the effects of an earlier decline in world saving in their analysis. Also see Sesit (1991) for some doubts concerning this analysis. The Council of Economic Advisers (1991) argues that real interest rates were boosted by European developments in late 1990. Such a shift in the overall demand for credit and rise in the real interest rate would be expected to create the usual credit crunch conditions in other economies as credit is diverted to Eastern Europe. This argument has not been raised, however, in the context of the 1990-91 U.S. credit crunch

14For example, Brunner and Meltzer (1968) emphasized the role of credit and asset prices, or interest rate spreads, in the transmission of monetary policy over the business cycle. See Bernanke (1990) for a recent study of interest fate spreads.

15Bernanke (1990) points out that the spread between the BAA bond rate and the AAA bond rate is a measure of default risk. 
Figure 4

Selected Interest Rate Spreads

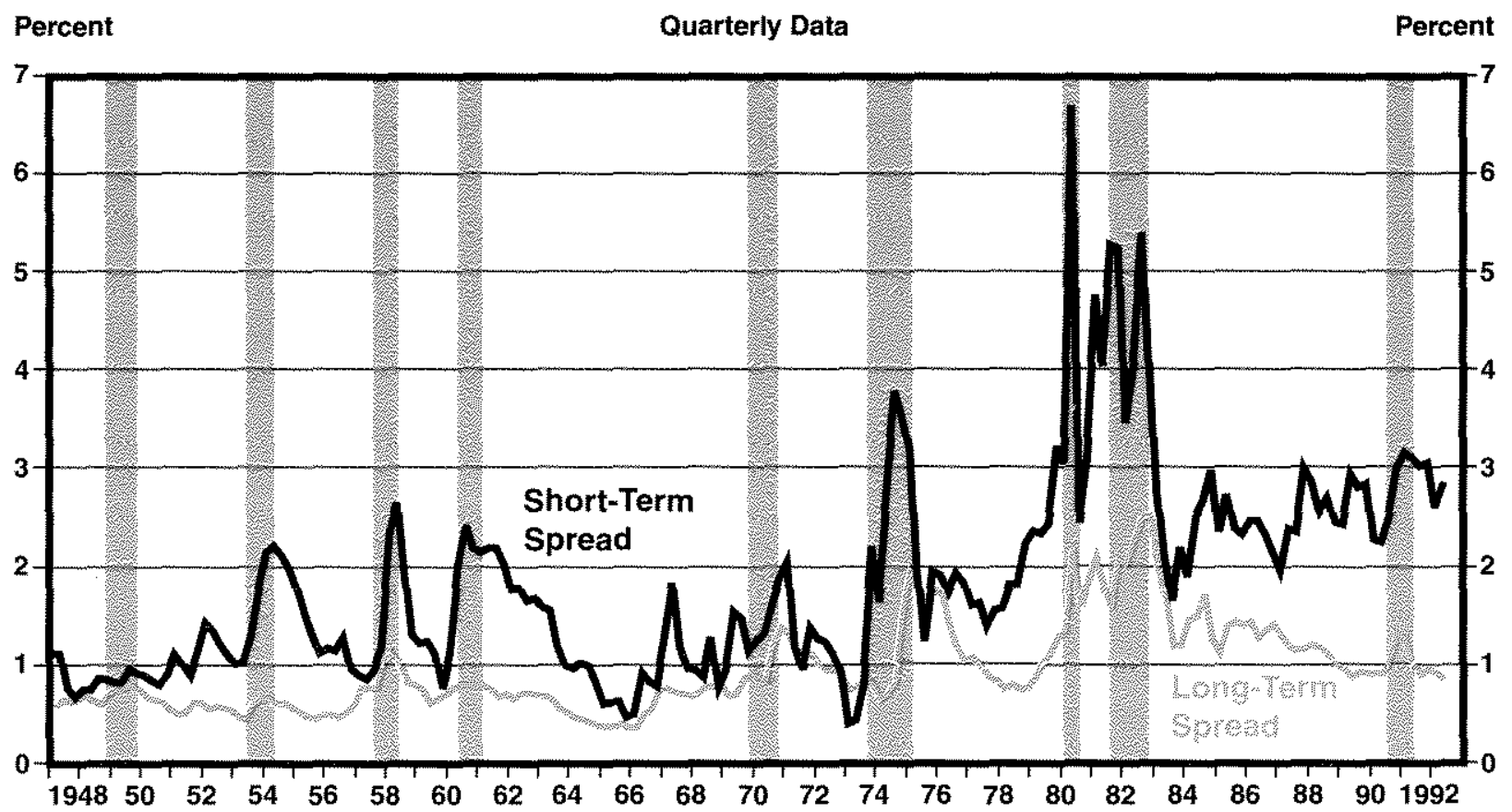

Long-term spread is the excess of the yield on BAA-rated bonds over AAA-rated bonds.

Short-term spread is the prime rate less the yield on 3-month Treasury bills.

Periods of business recession are indicated by the shaded areas.

Moreover; the short-term spread was lower than in the three previous recessions. While figure 4 shows that the price of risk rises in recessions, it provides insufficient evidence of bank unwillingness to lend.

Although bank willingness to lend is certainly a function of default risk, a bank's demand for funds to intermediate is also a factor. Figure 5 shows the spread between banks' lending and borrowing rates, where the prime rate is the lending rate and the interest rate paid on large negotiable certificates of deposit (CD) is used for the bank borrowing rate. A rise in this spread could reflect an increased reluctance to lend like that envisioned by credit crunch analysts, but this reluctance may simply reflect an assessment of the risk arising from a recession. ${ }^{16}$ This spread rose from 196 basis points in III/1990-when the recession started - to about 265 basis points at the end of the recession; it rose slightly more in the fourth quarter of 1991 .

The rise in the spread and its recent levels, however, are both smaller than the peak spreads observed in the 1980 and $1981-82$ recessions ${ }^{ \pm 7}$ While the spread in 1990-91 was higher than in the $1969-70$ and $1973-75$ recessions, the rise in the spread during each of the four previous recessions was larger than the rise during the most recent recession. Therefore, if an increase in the spread between the prime rate and the CD rate is associated with an increased unwill-
16 There is a distinct negative relationship between the prime rate and $C D$ rate spread in figure 5 and the growth rate of C\&l loans over the (available) sample period $1 / 1970$ to $11 / 1992$. The correlation between these two measures is -0.43 , which is statistically significant at the 1 percent level.
17The difference between movements in inflationary expectations in the most recent recession and in the previous recessions may explain pat of the difference. Changes in intlationary expectations, however, should affect both interest rates in the same direction. 
Figure 5

\section{Spread Between the Prime Rate and the Rate on 3-Month Certificates of Deposit}

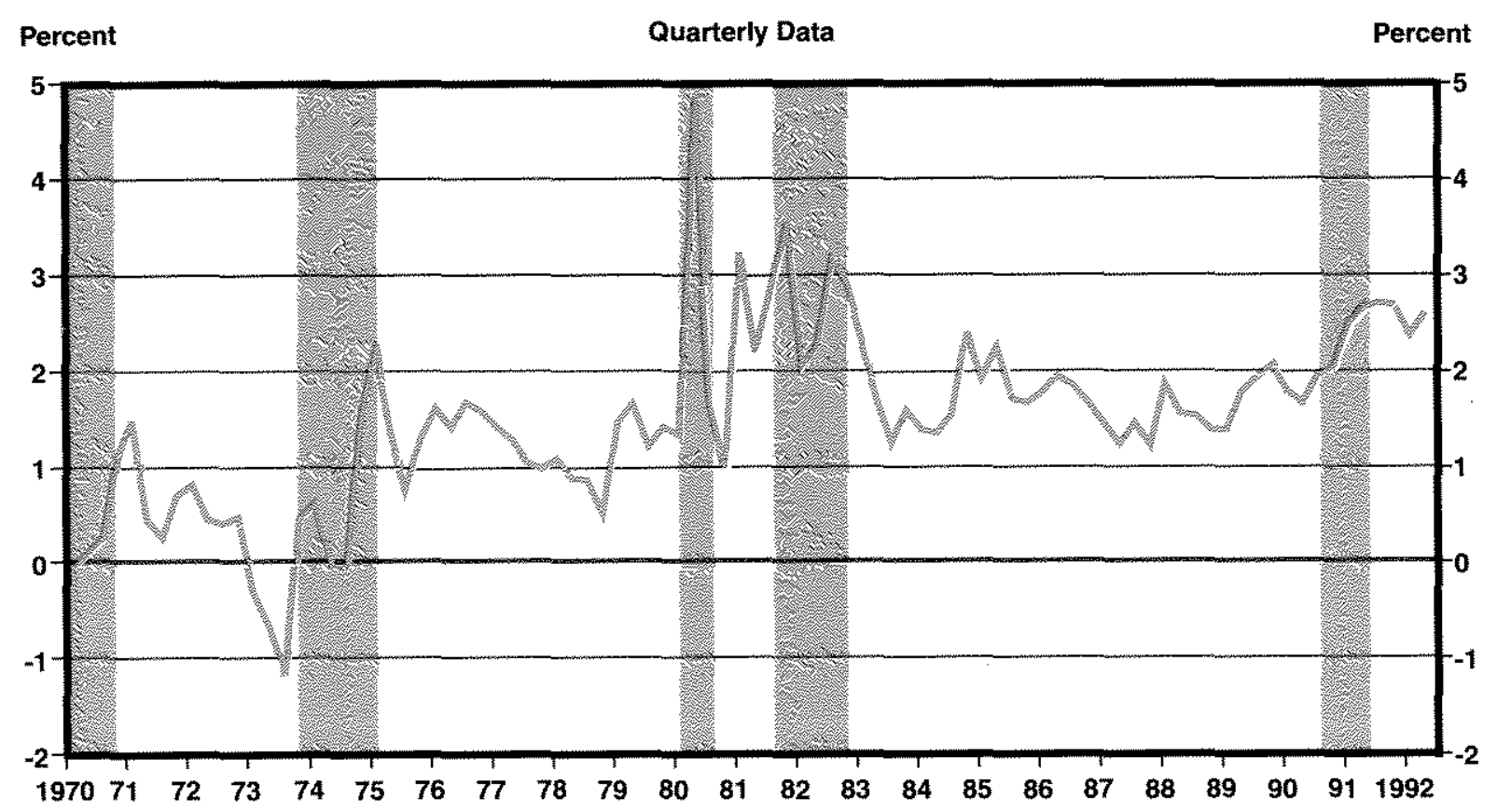

Periods of business recession are indicated by the shaded areas.

ingness to lend, then in the most recent case such unwillingness was smaller than usual. ${ }^{18}$

Another related measure that could indicate a rise in bankers' reluctance to lend is the spread on banks' borrowing rates compared to rates available to lenders elsewhere. Figure 6 shows how bank borrowing rates change relative to other safe, short-term rates during recessions. Because the intermediation process occurs through the initial issuance of bank liabilities (that is, a bank attracts deposits that it will then relend), a bank's demand for funds to intermediate should show up in the CD rate.

18 it is possible that the spread for some borrowers, or in some sectors or regions, rose unusually in this recession, perhaps reflecting some risk beyond those typicaly associated with recessions.

19See Gilbert (1976) for a discussion of the earlier episode and the typical weakness of loan demand early in a recovery.

20Figure 6 also shows that the rate on CDs generally increases at some point early in a recession. This rise probably occurs
Figure 6 shows that the spread between the three-month CD rate and the three-month Treasury bill, although somewhat volatile, always declines from peak to trough. Furthermore, this spread typically falls sharply late in recessions and for a while thereafter. For example, this spread fell through most of 1970 , at the beginning and end of the $1973-75$ recession, at the trough in 1980 and during much of the $1981-82$ recession. ${ }^{19}$ Generally, however, this spread appears to be relatively higher at some point in each recession than it was at the business cycle peak. ${ }^{20}$ Following a brief surge in the fourth quarter of 1990, the $C D$ rate declined at the end of the recession and

because of the perceived riskiness of CDs due to bank failure; however, since the "too-bignto-fail" doctrine, and especially since the savings and loan bailout, $C D$ s are about as sate as Treasury bills. Thus, this spread-as shown in figure 6- had moved to relatively low levels even before the latest recession. The decline in the spread immediately before the recession is consistent with an earlier decline in bank loan growth. 
Figure 6

\section{Spread Between the Rate on 3-Month Certificates of Deposit and the Rate on 3-Month Treasury Bills}

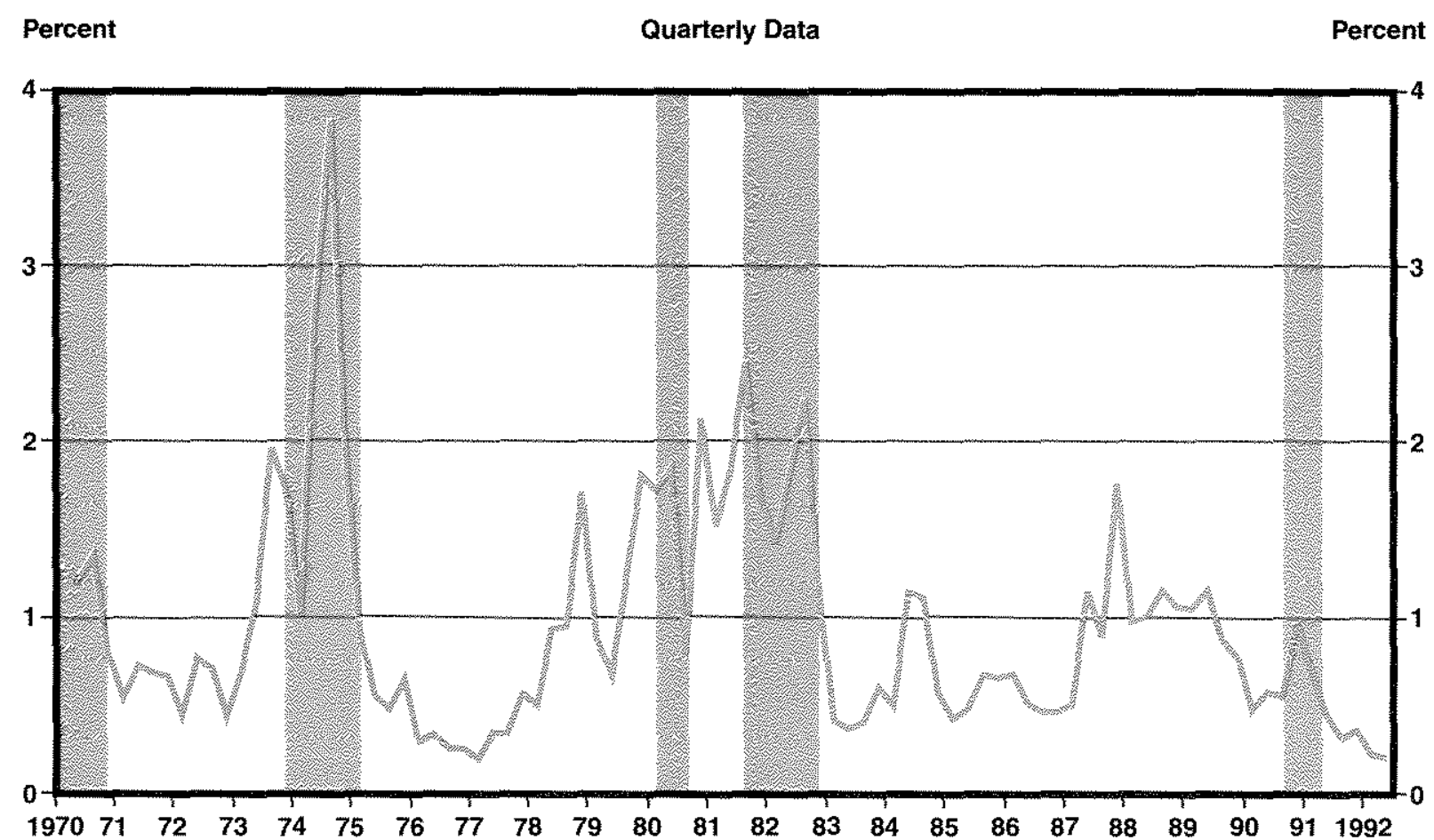

Periods of business recession are indicated by the shaded areas.

early in the recovery-just as it did previously.

By the third quarter of 1991, the spread between the $\mathrm{CD}$ rate and the Treasury bill rate had fallen to its lowest level since 1976-77. This narrowing of the spread (that is, a relative decline in the $\mathrm{CD}$ rate) and its relatively low level are consistent with reductions in banks' demand for funds-either because loan demand was weaker or because bankers were reluctant to lend. In either case, however, the recent decline in this spread is much smaller than the peak-to-trough decline in the four previous recessions.

The evidence on bank pricing indicates that the spread between the lending (prime) and borrowing (CD) rate widened during the recent recession, as it typically does, although not by as much. It also indicates that the prime rate rose and the $C D$ rate fell relative to the Treasury bill rate. The decline in the latter was not unusual, nor was it unusually large. Since it is not unusual for bank margins to rise in recessions or for the $\mathrm{CD}$ rate to fall at the end of recessions, these arguments, while consistent with the credit crunch hypothesis, do not support the view that bankers have been less willing to make business loans. The critical issue in reaching this conclusion is whether interest rate spreads reacted unusually in the most recent recession. As shown in figures 4 through 6, they did not.

So far we have focused on the specifics of a credit crunch-as hypothesized by a simple model for the demand and supply of creditand on the evidence from interest rate spreads. This evidence questions the supply-side argument behind the credit crunch hypothesis and shows the recent episode was not unusual relative to earlier instances when, others have argued, credit crunches occurred. This leaves open the issue of the source of movement in the demand for business credit at banks during these periods. The nexus between the demand for business loans and business inventories is explored below. 


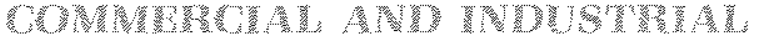

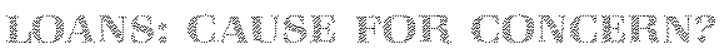

The U.S. economy officially entered a recession in the third quarter of 1990, when real GDP contracted at a 1.6 percent rate. Output continued to contract in the fourth quarter of 1990 and the first quarter of 1991, declining at a 2.9 percent rate over the threequarter period. One of the factors blamed for the recession was the unusual weakness of business loans. ${ }^{21}$ Even after signs of recovery began to emerge in the spring and summer of 1991, commercial and industrial loans at banks (hereafter, business loans) remained weak. For example, nominal commercial bank loans to business fell from $\$ 642.5$ billion in the fourth quarter of 1990 to $\$ 620.7$ billion in the fourth quarter of 1991, after rising at only a 0.1 percent rate over the previous year. By the first quarter of 1992 , business loans fell to $\$ 612.8$ billion; they dropped further in the second quarter to $\$ 602.8$ billion. As a result, concern about whether the recession had ended or whether the economy would have a double-dip, with real GDP resuming its earlier decline, continued well into the winter of 1991-92.

There are at least two reasons why analysts are concerned about business loan growth. The first is the concern raised by proponents of the credit crunch view of the recent recession: slow growth of bank lending could reflect unusual structural problems in banking. ${ }^{22}$ Second, slow growth in business loans is an indication that business activity is not expanding. If businesses are reluctant to expand, the potential for economic recovery is jeopardized. What is absent from the discussion, however, is the fact that business loans typically grow more slowly in recessions. This is examined in greater detail in the next section.

21See the references in footnote 1. For differing analyses, see Brenner and Schmidt (1991), Corcoran (1992). Furlong (1991) and Bacon and Wessel (1991), Heinemann (1991), Jordan (1992), Meltzer (1991), Passell (1991) and Prowse (1991). Syron (1991) attributes the weakness in bank loans and economic activity to a shortage of capitak induced by higher capital requirements and bank losses. Parry (1992) argues that policy-related changes in the real cost of intermediation have been appropriate, even if they have permanently changed the extent of bank intermediation.

22The Council of Economic Advisers (1991) discusses several reasons for the decline in bank credit growth. It notes, however, that the substitution of other debt should have offset the decline in bank lending. Strongin (1991) also stresses that credit reductions have been offset by increased equity financing. Bernanke and Lown (1991) point to an absence of business loan growth. They indicate that other sources of business loans show a decline that is unusually large for

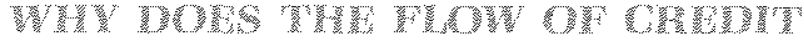

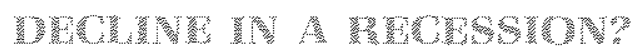

When sales slow, firms have an incentive to reduce production and employment to avoid an accumulation of undesired inventory. Such a reduction in output and employment constitutes a typical recession. But firms also alter their other investment decisions during recessions. For instance, firms also reduce their demand for new plant and equipment based on lower desired output levels and growing excess capacity. As a result, overall investment and its financing tend to decline during recessions.

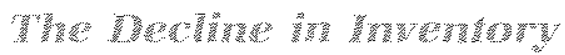

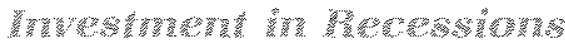

The role of inventory investment in recessions is especially important. Indeed, one principal type of recession is called an inventory recession because of the central role of changes in inventories. ${ }^{23}$ In an inventory recession, an unanticipated decline in sales growth leads to an undesired build-up of inventory followed by adjustments to production and employment. As firms reduce inventory to eliminate the initial excess, inventory investment becomes negative; however, such investment must eventually be restored to continue meeting the slower pace of expected sales. This eventual rise in inventory investment implies that some firms' production and sales have risen, thereby setting in motion an overall cyclical expansion. Thus, an inventory recession is characterized by, first, an initial rise in inventories relative to sales (before, or in, the initial stage of a recession), second, a subsequent decline in inventory investment to a negative pace, and finally, a rebound in inventory investment before or at the recession's end. them during recessions, reinforcing the view that the overatl demand for business loans fell, not the supply. They also provide evidence that New England banks' efforts to raise capital had a relatively small impact on bank lending, although not necessarily on business loans. Feldstein (1992) argues that the imposition of risk-based capital standards has restricted banks' ability to intermediate.

23The cyclical behavior of inventory investment and inventory recessions are described in more detail in Tatom (1977). The first effort to formally model the inventory cycle is Metzler (1941). Blinder and Maccini (1991) provide a recent review of the state of research on inventories. 
Figure 7

\section{Change in Business Inventories}

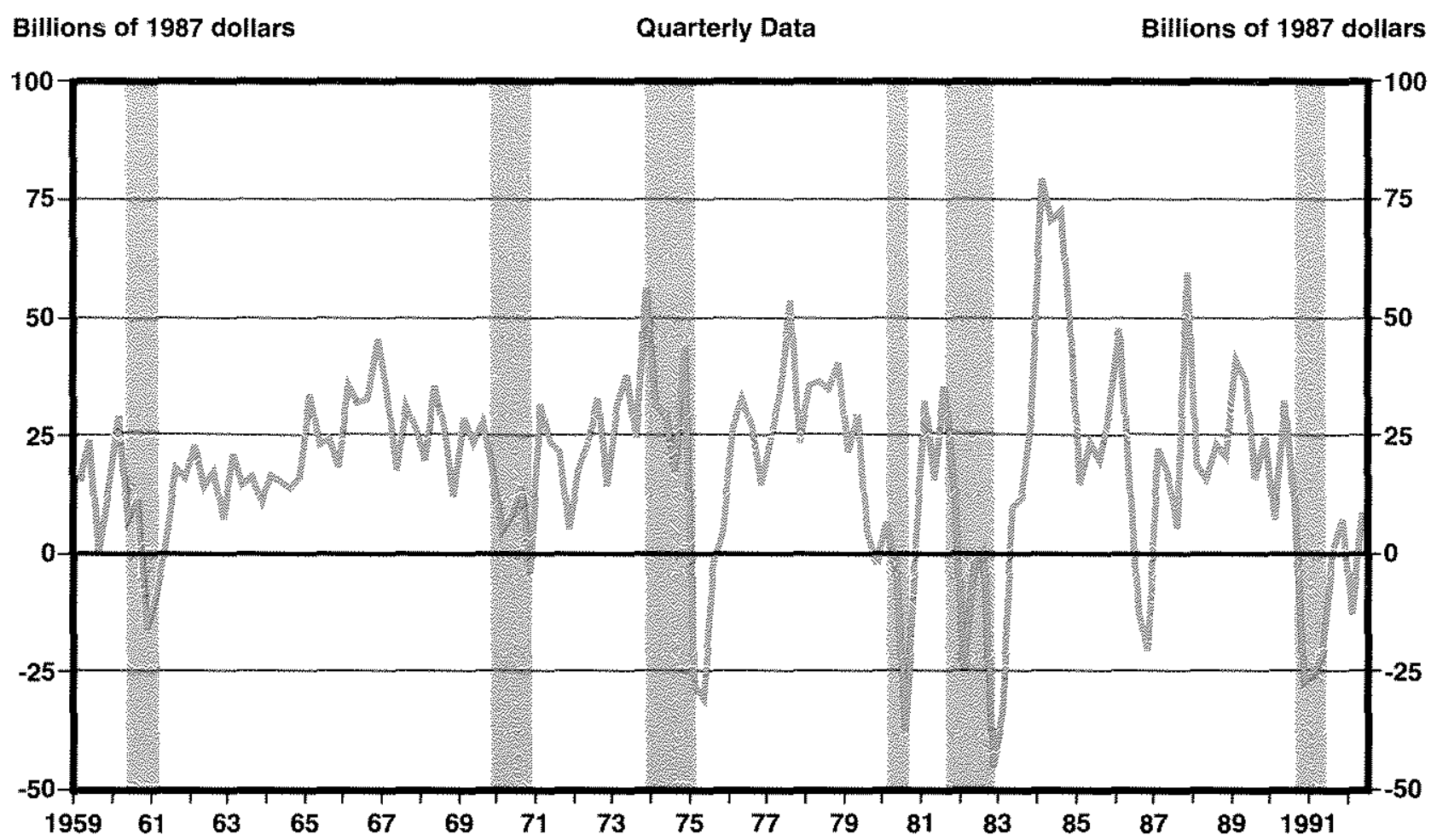

Periods of business recession are indicated by the shaded areas.

Figure 7 shows the change in inflation-adjusted business inventories since 1959. Inventory investment does not always rise unusually at the business cycle peaks. Indeed, in half the instances shown, including the latest, inventory investment falls at the business cycle peak. Also, it is uncommon for inventory investment to register increases at the end of a recession or in the trough quarter. It is not unusual for it to rise in the first quarter of the recovery. Such a rise occurred in seven of the past eight recessions, although, in four of these cases, inventory investment remained negative in the quarter following the business cycle trough. Therefore, while all recessions do not conform to the stereotypical inventory recession pattern, there is no question that movements in inventory investment play a central role in recessions. The decline in overall investment and real GDP in recessions is concentrated most heavily in their inventory investment component.

Table 2 shows that the decline in the constant. dollar change in business inventories accounts for much of the business cycle peak-to-trough decline in real GDP. Excluding the relatively large swings in inventory investment (as a share of the decline in GDP) in the 1960-61 and 1969-70 recessions, the decline in inventory investment in the most recent recession +48.2 percent) was fairly typical. It exceeded that in three of the previous eight recessions, although inventory investment already had declined rather substantially from early in $\mathbf{1 9 8 9}$ to the business cycle peak in II/1990. For the recent period of decline in real GDP (II/1990 to 1/1991), the decline in inventory investment of $\mathbf{5 4 . 6}$ percent of the production decline exceeded that in four of the previous eight recessions. 
Table 2

The Decline in Inventory Investment in Recessions

\begin{tabular}{|c|c|c|c|}
\hline $\begin{array}{l}\text { Recession } \\
\text { peak-trough }\end{array}$ & $\begin{array}{l}\text { Change in } \\
\text { real inventory } \\
\text { investment }{ }^{t}\end{array}$ & $\begin{array}{c}\text { Change in real } \\
\text { GDP1 }\end{array}$ & $\begin{array}{l}\text { Column } 1 \text { as } \\
\text { a percent } \\
\text { of column } 2\end{array}$ \\
\hline IV/1948-IV/1949 & $\$-28.3$ billion & $\$-20.9$ billion & $135.4 \%$ \\
\hline III/1953-1I/1954 & $-11.1(-18.4)$ & $-37.4(-43.3)$ & $29.7(42.5)$ \\
\hline $11 / / 1957-1 / 1958$ & $-20.1(-22.5)$ & $-44.9(-53.1)$ & $44.8(42.4)$ \\
\hline $1 \mid / 1960-1 / 1961$ & $-15.7(-45.5)$ & $5.7(-15.8)$ & $-275.4(288.0)$ \\
\hline N/1969-IV/1970 & $-22.5(-19.8)$ & $-1.8(-25.0)$ & $1250.0(79.2)$ \\
\hline IV/1973-I/1975 & -84.7 & -135.1 & 62.7 \\
\hline I/1980-1///1980 & $-44.3(-10.7)$ & $-97.3(-98.2)$ & $45.5(10.9)$ \\
\hline III/1981-IV/1982 & $-80.6(-35.0)$ & $-104.9(-110.1)$ & $76.8(31.8)$ \\
\hline $111 / 1990-11 / 1991$ & $-31.6(-57.9)$ & $-65.5(-106.0)$ & $48.2(54.6)$ \\
\hline
\end{tabular}

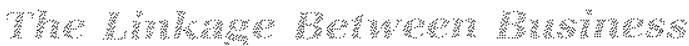

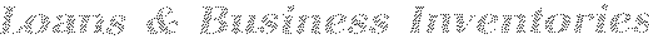

Inventory decisions are also central to business loan behavior during recessions. ${ }^{24}$ Since banks tend to hold short-term liabilities, which in large part are payable on demand, they have a strong incentive to hold relatively short-term loans. Thus, bank loans and lines of credit to business are principally related to business financing of shortterm assets, such as inventories. Inventory assets are crucial because they are superior collateral to receivables. Moreover, the value of receivables can disappear more easily than that of inventory in the event of default: inventory also can be taken over and liquidated more easily.

Figure 8 shows the stock of business inventories and business loans since 1959, both measured in nominal terms. ${ }^{25}$ Business loans and business inventories move together over time. For example, both rise slowly until 1973, then accelerate sharply until late 1974 . At the end of the $1973-75$ recession and during the early quarters of the recovery, business loans declined along with business inventories. The growth rates of each series appear to slow in the 1980 recession and at the end of the 1981-82 recession. Inventory growth is unusually slow from early 1982 to the end of 1986 compared with loan growth, however, Over this period, business loans rose from about 44 percent of inventories to about 59 percent, reflecting the slowing in inventory growth.

Since the end of 1986, both business loans and inventories have grown at about the same rate, keeping business loans at about 60 percent of inventories. Both measures declined in the recent recession, following a slowing in growth in 1989 and 1990. For example, from the first quarter of 1987 to the first quarter of 1989 , business loans rose at a 5.9 percent annual rate, while business inventories rose at a 7.9 percent rate. During the same interval, overall nominal final sales in the U.S, economy grew at a 7.9 percent rate. ${ }^{26}$ Over the next six quarters, final sales growth slowed to a 5.7 percent rate, while inventory growth slowed to a 4.3 percent rate and business loans slowed to a 3.0 percent rate

of business inventory typically is much larger than that of business loans.

$26 \mathrm{Final}$ sales is the sum of gross private domestic fixed investment, personal consumption expenditures, net exports and government purchases. GDP is the sum of final sales and the change in business inventories. 
Figure 8

\section{Business Loans and Business Inventories}

Billions of dollars

Quarterly Data

Billions of dollars

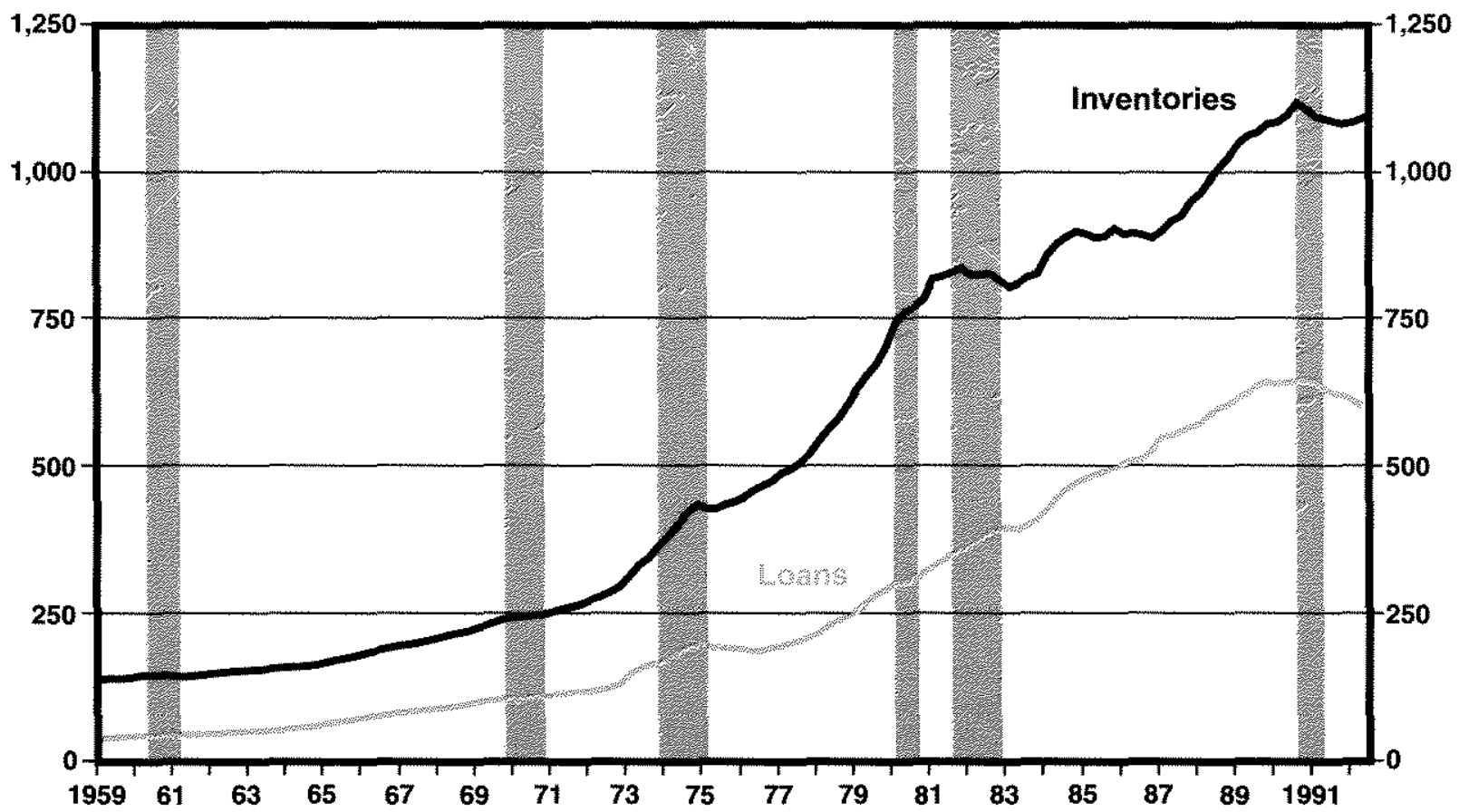

Periods of business recession are indicated by the shaded areas.

of advance. Finally, during the recent recession, from the third quarter of 1990 to the second quarter of 1991, final sales growth slowed to a 3.1 percent rate and inventory fell $\$ 27.6$ billion, or at a 3.3 percent rate. The decline in business loans over the recession totaled $\$ 11.9$ billiona 2.5 percent rate of decline.

The link between nominal business loans and nominal business inventories is more systematic than the simple upward trends in figure 8 might suggest. Quarter-to-quarter changes in business loans are statistically related to quarter-toquarter changes in the stock of inventories in a significant and positive fashion.

Figure 9 shows the change in business inventories and the change in business loans (both in current dollars); the two series are expressed as percentages of GDP to scale the data, but this has no effect on the close visual relationship between the two series. The correlation coefficient for these changes over the period II/1959-II/1992 is 0.52 , which is statistically significant at the 5 percent level.

Stronger evidence for the relationship between business loans and business inventories can be obtained from causality analysis. In simple terms, causality analysis examines the statistical direction of influence from one variable to another; in particular, it assesses whether there is a statistically significant, temporal sequence between changes in one measure and another. This issue is addressed in the appendix. The results there support the hypothesis that changes in business loans are significantly influenced by changes in business inventories. When inventory investment falls, as it does in every recession, it is not surprising, therefore, to see an accompanied weakness in commercial bank business loans.

\section{cractishon}

The recent decline in the growth of business loans at commercial banks reflects normal 


\section{Figure 9 \\ Quarterly Changes in Business Inventories and Business Loans (Percent of GDP)}

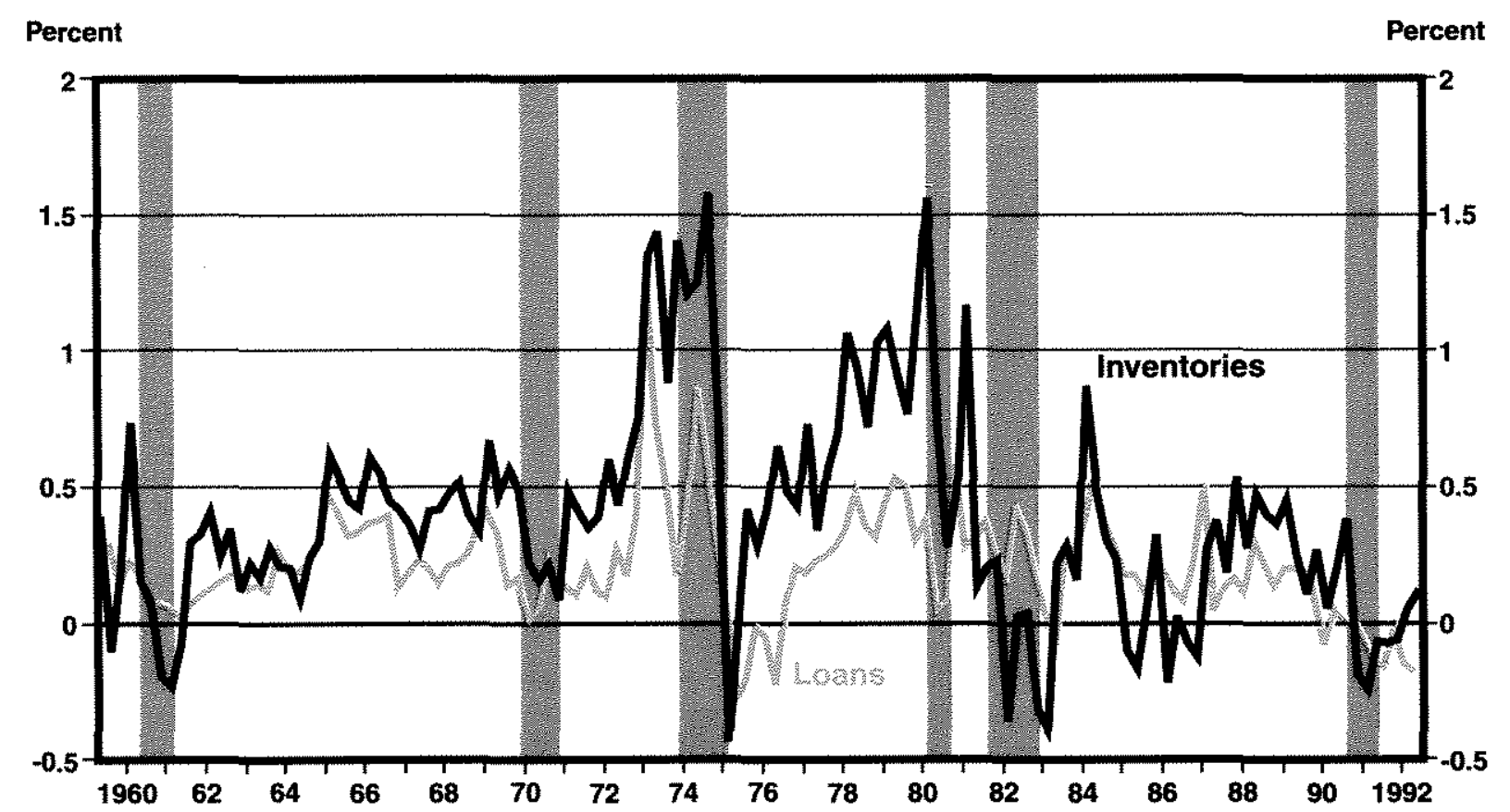

Periods of business recession are indicated by the shaded areas.

cyclical phenomena. While this decline has been referred to as a credit crunch, it is unlikely to have occurred because bankers were unusually reluctant to make business loans, as is sometimes suggested. Instead, as in earlier credit crunches/ recessions, the decline most likely originated on the credit demand side.

No doubt there are individual cases in which supply factors have been important in reducing credit availability. Indeed, some researchers have alleged that such occurrences explain, to a small extent, business loan slowings in some parts of the country owing to changes in bank capital requirements or other regulatory changes. These analyses generally do not control for the normal cyclical phenomena addressed here, however.

The decline in business loan growth in recessions is due, in large part, to the cyclical nature of business loan demand. Bank loans are typically short-term collateralized loans, so that the prime commercial asset that is financed by bank credit is inventories. The evidence presented here sug. gests that business loans and business inventory holdings are very closely related statistically, so that business loans and inventory move up or down in tandem. Since businesses typically reduce their desired inventory holdings during recessions, business loans at banks tend to decline as well.

An additional consideration is the recent movement in interest rates and interest rate spreads. As in earlier periods of so-called credit crunches, the recent decline in business loans has been accompanied by reductions in interest rates, particularly short-term rates. This behavior is inconsistent with a shortage of credit from a simple supply and demand perspective. While interest rate spreads for "risky" credit have risen recently, including the difference between bank lending and borrowing rates, this is also a normal cyclical phenomenon. This spread, as well as that between the prime rate and the three-month Treasury bill rate, have not been unusually large 
compared with previous recessions, nor has their increase been unusually large. Although the spread between the large CD rate and three-month Treasury bill rate has fallen, this too is not unusual in a recession nor in the initial stages of a recovery.

To summarize, the theory and evidence presented here suggests that recessions cause inventory demand and the growth of business borrowing to slow. To the extent that this argument and evidence characterize recent developments, the solution to the recent decline in credit growth is likely to be found, as usual, in a restoration of business inventory accumulation and its financing.

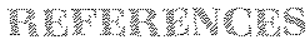

Anderson, Richard G.; and Robert $H$. Rasche. "What Do Money Market Models Tell Us about How to Implement Monetary Policy?" Journal of Money, Credit and Banking (November 1982), pp. 796-828.

Bacon, Kenneth H., and David Wessel. "Wary Lenders," Wall Street Journal, September 30, 1991.

Bank for International Settlements. 61st Annual Report (June 10, 1991).

Bermanke, Ben S. "On the Predictive Power of Interest Rates and Interest Rate Spreads," Federal Reserve Bank of Boston New England Economic Review (November/December 1990), pp. 51-68.

"Alternative Explanations of the Money-Income Correlation," Real Business Cycles, Real Exchange Rates and Actual Policies, Carnegie-Rochester Conference Series on Public Policy (Autumn 1986), pp. 49-100.

"Nonmonetary Effects of the Financial Crisis in the Propagation of the Great Depression, "American Economic Review (June 1983), pp. 257-76.

Bernanke, Ben S, and Cara S. Lown. "The Gredit Crunch;" Brookings Papers on Economic Activity (2:1991), pp. 205-47.

Bitinder, Alan S., and Louis J. Maccini, "Taking Stock: A Critical Assessment of Recent Research on Inventories," Journal of Economic Perspectives (Winter 1991), pp. 73-96.

Blinder, Alan S., and Joseph E. Stiglitz. "Money, Credit Constraints, and Economic Activity." American Economic Review (May 1983), pp. 297-302.

Brenner, Joel Glenn, and Susan Schmidt. "Bankers Say There's No 'Credit Crunch'," Washington Post, October 12, 1991.

Brunner, Karl, and Allan H. Meltzer. "Liquidity Traps for Money, Bank Credit, and Interest Rates," Journal of Political Economy (January/February 1968), pp. 1-37.

Burger, Albert E. "A Historical Analysis of the Credit Crunch of 1966," this Review (September 1969), pp. 13-30.

Corcoran, Patrick J. "The Credit Slowdown of 1989-91: The Role of Demand," paper presented at the 28th Annual Conference on Bank Structure and Competition, Federal Reserve Bank of Chicago, May 6m8, 1992.

Council of Economic Advisers. Economic Report of the President (Government Printing Office, 1992).

Economic Report of the President (Government Printing Office, 1991).
Duca, John V., and David D. VanHoose. "Loan Commitments and Optimal Monetary Policy," Journal of Money, Credit and Banking (May 1990), pp. 178-94.

Feldstein, Martin. "Revise Bank Capital Standards Now;" Wall Street Journal, March 6, 1992.

Forrestal, Robert P. "Policy Implications of a Credit Crunch," speech delivered at the Conference on "Credit Crunches-Causes and Cures," Wellington, New Zealand, August 16, 1991.

Furlong, Fred. "Financial Constraints and Bank Credit," Federal Reserve Bank of San Francisco Weekly Letter (May 24, 1991).

Gertler, Mark. "Financial Structure and Aggregate Economic Activity: An Overview," Journal of Money, Credit and Banking (August 1988), pp. 559-88.

Gertler, Mark, and R. Glenn Hubbard. "Financial Factors in Business Fluctuations," National Bureau of Economic Research, Working Paper No. 2758 (November 1988).

Gilbert, R. Alton. "Requiem for Regulation Q: What It Did and Why It Passed Away," this Review (February 1986), pp. 22-37.

"Bank Financing of the Recovery," this Review (July 1976), pp. 2-9.

Gilbert, R. Afton, and Mack Ott. 'Why the Big Rise in Business Loans at Banks Last Year?' this Review (March 1985) pp. 5-13.

Goldfeld, Stephen M. Commercial Bank Behavior and Economic Activity (North Holland: Amsterdam, 1966).

Greenspan, Alan. "Statements to Congress," Federal Reserve Bulletin (May 1991), pp. 300-310.

Hamilton, James D. "Monetary Factors in the Great Depression," Journal of Monetary Economics (March 1987), pp. 145-69.

Haubrich, Joseph G. "Do Excess Reserves Reveal Credit Crunches?" Federal Reserve Bank of Cleveland Economic Commentary (July 15, 1991).

Heinemann, $H$. Eric. "The 'Credit Crunch' Is a Red Herring," Christian Science Monitor, October 1, 1991.

James, Christopher. "Some Evidence on the Uniqueness of Bank Loans," Journal of Financial Economics (December 1987), pp. 217-35.

Jordan, Jerry 1.. "The Credit Crunch: A Monetarist's Perspective," paper presented at the 28th Annual Conference on Bank Structure and Competition, Federal Reserve Bank of Chicago, May 7, 1992.

Judd, John P., and John L. Scadding. "Liability Management, Bank Loans, And Deposit 'Market' Disequilibrium," Federal Reserve Bank of San Francisco Economic Review (Summer 1981), pp. 21-44

Kahn, George A. "Does More Money Mean More Bank Loans?" Federal Reserve Bank of Kansas City Economic Review (July/August 1991), pp. 21-31.

Kaufman, Henry. "Credit Crunches: The Deregulators Were Wrong," Wall Street doumal, October 9, 1991.

LaWare, John P. "Setting the Global Scene: A Global Credit Crunch?" speech delivered at the Conference on "Credit Crunches-Causes and Cures," Wellington, New zealand, August 15, 1991.

Meltzer, Alan H. "There is No Credit Crunch," Wall Street Journal, February 8, 1991.

Metzler, Lloyd A. "The Nature and Stability of Inventory Cycles," Review of Economic Statistics (August 1941), pp. 113-29. 
O'Brien, Paul Francis, and Frank Browne. "A Credit Crunch? The Recent Slowdown in Bank Lending and its Implications for Monetary Policy, "Organization for Economic Cooperation and Development Working Paper No. 107, 1992.

Parry, Robert T. "The Problem of Weak Credit Markets: A Monetary Policymaker's View;" Federal Reserve Bank of San Francisco Weekly Letter (January 3, 1992).

Passell, Peter. "Capital Crunch: Capitol Quandary," New York Times, November 6, 1991.

Plosser, Charles 1. "Money And Business Cycles: A Real Business Cycle Interpretation," in Michael T. Belongia, ed., Monetary Policy on the 75th Anniversary of the Federal Resenve System (Kluwer, 1991), pp. 245-74.

Prowse, Michael. "The Credit Crunch as Scapegoat," Financial Times, November 18, 1991.

Reuters News Service. "Japan Predicts Capital Crunch," International Herald Tribune, December 4, $1991 \mathrm{ta}$

"France Sees No 'Crunch' in Lending Slowdown," International Herald Tribune, December 12, 1991b.

Schreft, Stacey L. "Credit Controls: 1980," Federal Reserve Bank of Richmond Economic Review (November/December 1990), pp. $25 \cdot 55$.

Sesit, Michael R. "Fears of a Global Credit Crunch Are Overdone, Some Analysts Say," Wall Street Journal Europe, November 5, 1991.
Strongin, Steven. "Credit Flows and the Credit Crunch," Federal Reserve Bank of Chicago, Chicago Fed Letter (November 1991)

Syron, Richard F. "Are We Experiencing a Credit Crunch?" Federal Reserve Bank of Boston New England Economic Aeview (July/August 1991), pp. 3-10.

Tatom, John A. "Two Views of the Effects of Government Budget Deficits in the 1980s," this Review (October 1985), pp. 5-16.

"A Perspective on the Federal Deficit Problem," this Review (December 1984), pp. 5-17.

"Energy Prices and Short-Run Economic Performance," this Review (January 1981), pp. 3-17.

"Anventory Investment in the Recent Recession and Recovery" this Review (April 1977), pp. 2-9.

Walsh, Carl E. "The Credit Crunch and The Real Bils Doctrine," Federal Reserve Bank of San Francisco Weekly Letter (May 3, 1991).

Woinifower, Abert M. "The Central Role of Credit Crunches in Recent Financial History," Brookings Papers on Economic Activity (2:1980), pp. 277-339.

\section{Avpendix}

\section{Pusposs Loans and Bushess Inventomes: Some Statisterell Wvillence}

The relationship between inventory decisions and the growth of business loans can be examined using a straightforward causality test, which tests the statistical significance of the temporal sequence between measures that are hypothesized to be related. The growth rate of business loans $(\dot{\mathrm{L}}=400 \Delta \mathrm{inL})$ and business inventories (i $=400 \Delta \operatorname{lnl}$ ) can be examined to see (1) whether one measure "causes" the other; (2) whether they each cause the other (bi-directional causality) or (3) whether they are statistically independent. This is done by examining the statistical significance of past values of one measure in explaining the other, controlling for the time series properties of the other.

Considered alone, the growth in business loans (i) and in business inventories (i) are firstand third-order autoregressive series, AR1 and AR3, respectively, which means that current values of each are highly related to their own past value one quarter earlier and three quarters earlier, respectively, but not to earlier changes.

The statistical analysis presented here uses variables measured in nominal terms because the credit crunch hypothesis concerns the effects of nominal bank credit and the latter finances, in part, nominal inventory. When the procedures are performed on the same variables measured in constant-dollar terms, the results are essentially the same and the conclusions are not altered. 
To conduct the causality tests, up to eight past values of each variable were added to the autoregressive model of the other to see if one variable is statistically significant in explaining future values of the other.

For loan growth during the period from II/1959 to II/1992, the only statistically significant relationship between the two measures is:

$$
\begin{aligned}
& \text { (1) } \dot{\mathrm{L}}_{\mathrm{t}}=2.124+0.236 \dot{\mathrm{I}}_{\mathrm{t}-1}+0.565 \dot{\mathrm{L}}_{\mathrm{t}-1} \\
& \begin{array}{lll}
(2.77) \quad(2.47) \quad(7.13)
\end{array} \\
& \overline{\mathrm{R}}^{2}=0.46 \quad \text { S.E. }=5.586 \quad \text { D.W. }=1.85
\end{aligned}
$$

This equation indicates that inventory growth causes business loan growth, because the coefficient on the change in inventory (0.236) is significantly different from zero at a 5 percent level according to the relatively high value of the t-statistic given in parentheses. The adjusted $\mathrm{R}^{2}$ and Durbin-Watson (D.W.) statistics suggest, respectively, that there is a strong relationship and that the first lag value of the dependent variable $\left(\dot{\mathrm{L}}_{1-1}\right)$ is sufficient for removing any problematical serial correlation in the errors of the estimated equation. ${ }^{2}$ No other lagged value of $\dot{I}$ or $\dot{L}$ or combination of lagged values is statistically significant.

While the evidence presented here indicates that changes in inventories result in changes in business loans, there is nonetheless some evidence of reverse causality-although the effect is ephemeral in nature. In particular, the best time series representation for inventory growth is an AR(3) model. The inventory equation similar to equation 1 , for the period I/1960 to $\mathrm{I} / 1 \mathrm{1992}$, is:

$$
\begin{aligned}
& \text { (2) } \dot{I}_{t}=1.157+0.560 \dot{I}_{t^{\mu 3}}-0.079 \dot{I}_{1-2}+0.274 \dot{I}_{1-3} \\
& \begin{array}{llll}
(1.88) & (6.32) & (-0.80) & (3.31)
\end{array} \\
& +0.264 \dot{\mathrm{L}}_{\mathrm{t}-1}-0.216 \dot{\mathrm{L}}_{\mathrm{i}-2} \\
& \text { (3.76) } \quad(-3.02) \\
& \overline{\mathrm{R}}^{2}=0.55 \quad \text { S.E. }=4.200 \quad \text { D.W. }=1.92
\end{aligned}
$$

Since the lagged terms on the change in business loans are approximately equal in magnitude and opposite in sign, it is possible that only a transitory effect is present, so that a rise in loan growth has no effect on inventory growth after two quarters.

To test this hypothesis, the coefficients on the two lags of business loan growth were constrained to sum to zero. The resulting estimate is:

$$
\begin{aligned}
& \text { (3) } \dot{I}_{1}=\underset{(2.33)}{1.318}+\underset{(6.98)}{0.580} \dot{I}_{t-1}-\underset{(-0.69)}{0.067} \dot{I}_{t-2} \\
& +0.281 \dot{\mathrm{I}}_{1-3}+0.241 \Delta \dot{\mathrm{L}}_{\mathrm{t}-1} \\
& \text { (3.42) } \\
& \text { (3.96) } \\
& \overline{\mathbf{R}}^{2}=0.55 \quad \text { S.E }=4.189 \quad \text { D.W. }=1.94
\end{aligned}
$$

A test of the restriction (that is, regressions 3 and 2 , respectively) yields an $\mathrm{F}_{1,124}=0.42$, which is not statistically significant. Thus, one cannot reject the hypothesis that there is a transitory causal link from increased loan growth to increased inventory growth. After two quarters, however, a change in business loan growth has no statistically significant effect on business inventory growth. ${ }^{3}$ These results suggest that policies designed to increase bank lending, taken alone, are unlikely to raise inventory investment, which is one of the principal effects expected by proponents of the credit crunch/recession linkage. Moreover, these results also reaffirm the behavior of business loans during and immediately following a recession. ${ }^{4}$

4According to Gilbert and Ott (1985), business loans at large banks typically remain at their trough level during the first year of the recovery, before giving way to moderate growth in the second year.
2Both business loans and inventory are integrated of order reported here.

Equations 1 and 2 , or 1 and 3 , were also estimated using the seemingly-unrelated-regression method to allow for contemporaneous correlations of the error terms. This does not affect the causality conclusions. The inclusion of the lagged residual from an estimated cointegrating vector for the levels also does not alter these results. 